\title{
VYUŽITÍ FRANCOUZSKÉHO PŘÍSTUPU PRO REGENERACE BROWNFIELDS V ČR
}

\section{USE OF THE FRENCH APPROACH TO THE REGENERATION OF BROWNFIELD SITES IN THE CZECH REPUBLIC}

\author{
ING. MONIKA VYŠKOVSKÁ \\ Katedra regionální ekonomie a správy $\mid$ Dep. of Regional Economics and Administration \\ Ekonomicko-správni fakulta Faculty of Economics and Administration \\ Masarykova univerzita Masaryk university \\ $\triangle$ Lipová 41a, 60200 Brno, Czech Republic \\ E-mail: monavyskovska@seznam.cz
}

\begin{abstract}
Anotace
Brownfields představuji zcela nebo částečně opuštěná, zanedbaná území, se kterými může být spojena kontaminace. Pozemky negativně ovlivňuji ekonomickou, sociální a environmentální situaci regionu. Ignorováni lokalit není v souladu s principy udržitelnosti. Proto je nezbytná jejich regenerace. Regenerace je složitý a nákladný proces, který se často neobejde bez zapojení ze strany veřejného sektoru. Zemi, která má s regeneracemi řadu zkušeností je Francie. Otázky řešeni problému se zde dostávaly do popredí již v 70. letech 20. století. Na územi Č $R$ se od konce 90. let 20. stoletív důsledku změny politického režimu a následné transformace hospodářstvi rovněž začaly objevovat lokality typu brownfields. Přes určité snahy o regenerace se v $\check{C} R$ stále nachází velké množství těchto ploch a ČR stále hledá cestu, jak k lokalitám přistupovat. Článek má za cíl poukázat na jedny z významných nástrojů využivaných ve Francii, které by mohly sloužit jako inspirace pro ČR. Za tyto nástroje lze považovat Etablissement public foncier a nástroj umožnujici spolupráci veřejného a soukromého sektoru Société d'économie mixte. Nástroje umožňuji rozložit nejen rizika spojená s regeneracemi brownfields, ale předevšim vysoké finančni náklady mezi vice subjektů a tím urychlit a usnadnit proces regenerací. Pro naplněni cíle jsou využity metody analýzy a syntézy. Pro popis dosavadnich poznatků a zkušeností je využita metoda deskriptivní.
\end{abstract}

\section{Klíčová slova}

brownfields, regenerace brownfields, Etablissement public foncier, Société économie mixte, udržitelný rozvoj

\section{Annotation}

Brownfields are totally or partially abandoned, neglected area, that can be linked to contamination. The land negatively affect economic, social and environmental situation of the region. Ignoring this site is not in accordance with the principles of sustainability. Therefore, their regeneration is necessary. Regeneration is a complex and costly process that often depends on the involvement of the public sector. A country that has a lot of experience with regeneration is France. Questions to solve the problem here getting into the foreground as early as the 70th 20th century. In the Czech Republic since the end of the 90th 20th century due to the change of the political regime and the subsequent transformation of the economy also began to appear brownfield sites. Despite some efforts to regeneration in the Czech Republic is still a large number of these areas and the Czech Republic are still looking for a way to access the sites. Article aims to highlight some of the important tools used in France, which could serve as an inspiration for the country. These tools can be Etablissement public foncier and the means of cooperation between the public and private sectors Société économie mixte. Tools allow you not only to spread the risks associated with brownfield regeneration, but also high financial costs among multiple entities and thus accelerate and facilitate the process of regeneration. To fulfill the objectives are utilized methods of analysis and synthesis. For a description of current knowledge and experience is used descriptive method. 
Key words

brownfields, brownfield regeneration, Etablissement Public Foncier, Société économie mixte, sustainable development

JEL classification: $X 12$

\section{Úvod}

Brownfields jsou lokality zcela nebo částečně opuštěné, původně sloužící průmyslovým, zemědělským, vojenským či jiným aktivitám, se kterými se může vázat ekologická zátěž. Představují negativní dopad na sociální, ekonomickou, ekologickou a udržitelnou situaci regionu. Chátrající budovy kazí celkovou image území, působí jako negativní externalita na okolní nemovitosti, snižují jejich hodnotu a zároveň odrazují potenciální investory. Mohou se stát ohniskem sociálně patologických jevů. Velice často je s nimi spojená kontaminace, která se může také šířit do okolí a ohrožovat životní prostředí a obyvatelstvo. Budovy jsou často v havarijním stavu, mohou se zbortit a někoho zranit. Neřešením problému a ignorováním brownfields dochází k ohrožení udržitelného rozvoje regionu, protože brownfields představují zablokovaná a nevyužívaná území. V př́padě, že nebude vyvíjena snaha o jejich regeneraci, investoři budou realizovat novou výstavbu na greenfields, zabírat zemědělskou půdu a bude docházet k rozrůstání měst.

Proto je nezbytná jejich regenerace, která představuje složitý a nákladný proces vyžadující také zásahy veřejného sektoru. Regenerace či rekonverze brownfields spočívá v rekonstrukci území za účelem jeho opětovného využívání. V určitých př́ípadech rekonstrukce není možná a regeneraci je třeba provést ve dvou krocích. První krok spočívá v rekultivaci, během které dojde k vyčištění území a k jeho navrácení do stavu srovnatelného s greenfields. Druhým krokem je obnova, tedy navrácení lokality zpět k využívání (CzechInvest, 2008).

Regenerace závisí na mnoha faktorech. Mezi tyto faktory bychom mohli zařadit polohu, ekologickou zátěž, majetkové vztahy, existenci infrastruktury, vztah obce a občanů a jedním z nejdůležitějších faktorů jsou finance (Kadeřábková, Pecha, 2009). Finanční prostředky nezbytné pro regeneraci často převyšují hodnotu lokality na trhu nemovitostí poté, co dojde k jejich obnově. Velice často je proto nezbytné do procesu zapojit veřejný sektor a veřejné finance.

ČR patři mezi země, které lze zařadit mezi pokročilé začátečníky při řešení brownfields, se kterými se začala potýkat na konci 90 . let 20 . století. I přes patrné snahy o řešení problému se zde stále nachází velké množství těchto nevyřešených a chátrajících území. Mezi nejčastěji uváděné bariéry bránící regeneraci patří nedostatek financí, nejasný záměr, co s lokalitami dál a nedostatek zkušeností s řízením brownfields.

Článek má za cíl poukázat na jedny z nejvýznamnějších nástrojů využívaných ve Francii, které by mohly napomoci $\mathrm{v}$ procesech regenerací $\mathrm{v}$ ČR a poukázat tak na možné prř́nosy $\mathrm{v}$ př́padě zavedení podobných nástrojů. Článek zároveň poukazuje na konkrétní př́ípady využití těchto nástrojů v jednom, brownfields nejvíc postiženém francouzském regionu. Pro naplnění cíle jsou využity metody analýzy a syntézy. Pro potřeby popsání dosavadních poznatků je využita metoda deskriptivní.

Od konce 70 . let 20. století se Francie začala potýkat se změnou ve struktuře hospodářství. Útlum průmyslu měl za následek vznik řady opuštěných průmyslových areálů neboli friches industrielles (francouzské označení pro průmyslové brownfields) představujících nebezpečí pro obyvatelstvo i životní prostředí. Mezi nejpostiženější regiony lze zařadit Nord-Pas-de-Calais, Rhône Alpes, Champagne-Ardenne, Lorraine a Ile-de-France. První programy regenerací byly rízeny centrálně a zaměřeny na uvedení ploch do stavu „, $0^{\prime}$. Ze strany státu se projevovaly snahy směřovat do výše zmíněných regionů novou výrobu. Na začátku 80. let docházelo k decentralizaci, regenerace friches industrielles začala být řešena na úrovni jednotlivých regionů a měst, které získaly kompetence 
v územním a ekonomickém rozvoji. Silně poznamenané regiony si vydobyly začlenění regenerací friches industrielles do Contrat de Plan Etat Régional, později Contrat de Projet Etat Régional (smlouvy mezi státem a regiony). V 90. letech se Francie ocitla již ve druhé fázi regenerací zaměřující se na městské prostředí a kromě sociálního a ekonomického rozvoje bylo do rekonverzí zahrnuto také hledisko environmentální a udržitelný rozvoj. Friches představovaly menší pozemky umístěné ve městech. Problematika regenerací se tak začlenila do oblasti obnovy měst. Jen nejpostiženější regiony typu Nord-Pas-de-Calais mají dodnes začleněny problematiku friches do rozsáhlejších regionálních strategií (Doležalová, 2004). Francie patř́ tedy mezi země, která má většinu bývalých průmyslových areálu dnes již vyřešenou. Výrazně $\mathrm{k}$ tomu napomohla organizace Etablissement public foncier (Veřejná pozemková organizace) a spolupráce veřejného a soukromého sektoru prostřednictvím Société d'économie mixte.

\section{Region Nord-Pas-de-Calais}

V regionu Nord-Pas-de-Calais se nacházelo nejvíce lokalit typu brownfields, které zde vznikly v důsledku útlumu sekundárního sektoru. Region byl zaměřený na průmysl báňský, metalurgický a textilní. Textilní průmysl se soustředil do aglomerací Roubaix, Tourcoing, Lille, Calaisis a jih departmentu Nord. Těžební a metalurgický průmysl se soustředil do oblasti Bassin Minier. Metalurgický průmysl byl koncentrován také v oblasti vallée de la Chambre a Dunkerquois. Mezi lety 1970-1990 se region potýkal s vysokou mírou nezaměstnanosti způsobenou úpadkem zmíněných průmyslových aktivit. Zanikla zde více než polovina pracovních míst, což mělo za následek emigraci obyvatel do jiných regionů Francie, případně do zahraničí. Dalším negativním důsledkem krize byl vznik až 10000 ha friches majících negativní dopad na životní prostředí. V roce 1990 bylo zaznamenáno, že $50 \%$ friches ve Francii se nachází právě na území regionu. Nejvíce postiženou oblastí byla uhelná pánev Bassin Minier, kde se koncentrovalo $75 \%$ daného postiženého území. Průmysl těžební a metalurgický po sobě zanechal degradované území, se kterým se často vázalo také znečištění. Textilní průmysl po sobě zanechal budovy umístěné zejména $\mathrm{v}$ centrech aglomerací a stal se tak problémem, který trápil nejen tamní obyvatele, ale také návštěvníky a dojíždějící za prací. Povědomí o problémech spojených s těmito lokalitami dalo vzniknout specifické politice friches industrielles. Nejvýznamnější institucí, která přispěla k regeneraci těchto oblastí, byla organizace Etablissement public foncier, která v regionu působí dodnes (Etablissement public foncier, 2006).

\subsection{Regionální úroveň}

\section{Etablissement Public Foncier}

Jedna $\mathrm{z}$ nejdůležitějších organizací $\mathrm{s}$ významným prínosem $\mathrm{v}$ procesech rekonverzí friches, Etablissement public foncier (EPF, Veřejná pozemková organizace), vznikla na konci 80. let minulého století. Zásahy instituce, která přispěla ke změně celkového rázu území a zlepšení kvality života zdejších obyvatel lze vidět zejména v oblasti Bassin Minier. V jejich pravomocech je nakupování, upravování, spravování a následný prodej regenerovaných pozemků. Pod úpravou rozumíme jen demolice, zazelenění a terénní úpravy. Nemohou vybavovat území infrastrukturou, pořizovat územně plánovací dokumentaci a rozparcelovat pozemek. Instituce spolupracují s obcemi, departmenty a regiony na základě tzv. convetion-cadre (rámcové dohody). Organizace předpřipraví pozemky a místní samosprávy je následně od nich odkoupí, aby zde mohli realizovat již připravený projekt (Doležalová, 2004). Orientace a směry akcí jsou zakotveny v sedmiletých plánech Programme Pluriannuel d'Intervention Foncière (víceletý program intervencí).

Zdrojem jejich př́ijmu je také taxe spéciale d'équipement (TSE, speciální rozvojová daň). Daň se přidává $\mathrm{k}$ výnosům $\mathrm{z}$ místních daní, kterými jsou taxe foncière sur les propriétés bâties et non bâties (daň ze zastavěného a nezastavěného území), taxe d'habitation (daň z bydlení), taxe professionnelle (daň obchodní). Výše daně je variabilní v závislosti na plánovaných operacích projektech pro daný rok. Nepřesáhne však nikdy $20 €$ na obyvatele s trvalým bydlištěm v daném území. Mezi další zdroje př́ijmů patř́ kromě dotace od státu. Nord-Pas-de-Calais má rekonverze zahrnuty v Contrat de projets état-région (CPER, Smlouvy mezi státem a regionem) a regenerace jsou tak financovány ze státních prostředků. Dále je organizace může obdržet dotace od místních samospráv, EU a dalších veřejných a 
soukromých organizací. Př́padně se pro ni nabízí možnost úvěru a zároveň má zisk z prodeje regenerovaných pozemků (Etablissement public foncier Nord-Pas-de-Calais, 2013).

EPF realizovala v letech od počátku své existence až do konce roku 2004 celkem 293 operací. Celkové finanční náklady na provedení těchto operací činily $149687804 €$ a průměrná částka na každou z nich se pohybovala ve výši $510880 €$. Celková regenerovaná plocha v departmentu Nord činila 2343 ha a v departmentu Pas-de-Calais 2409 ha. Většina operací uskutečněných EPF se soustředila do oblasti uhelné pánve Bassin Minier (Etablissement public foncier Nord-Pas-de-Calais, 2006). Finanční zdroje uskutečněných operací uvádí následující tabulka. Jednalo se převážně o prostředky strukturálních fondů EU, státu, regionů a místních samospráv.

Tabulka č. 1: Finanční zdroje uskutečněných operací $(€)$

\begin{tabular}{|c|c|c|c|c|c|c|}
\hline $\begin{array}{l}\text { Období } \\
\text { CPER }\end{array}$ & $\mathbf{E U}$ & Stát & Region & Města & Ostatní & Celkem \\
\hline 1989-1993 & $\begin{array}{l}9626926 \\
- \\
30 \%\end{array}$ & $\begin{array}{l}16044877 \\
- \\
50 \%\end{array}$ & $\begin{array}{l}6417951 \\
- \\
20 \%\end{array}$ & & & $\begin{array}{l}32089754 \\
- \\
100 \%\end{array}$ \\
\hline 1994-1999 & $\begin{array}{l}40649722 \\
- \\
54,8 \%\end{array}$ & $\begin{array}{l}23822754 \\
- \\
32,1 \%\end{array}$ & $\begin{array}{l}9642626 \\
- \\
13 \%\end{array}$ & $\begin{array}{l}23937 \\
- \\
0,1 \%\end{array}$ & & $\begin{array}{l}74139009 \\
- \\
100 \%\end{array}$ \\
\hline 2000-2003 & $\begin{array}{l}13547383 \\
- \\
47,3 \%\end{array}$ & $\begin{array}{l}6170201 \\
- \\
21,5 \%\end{array}$ & $\begin{array}{l}1975936 \\
- \\
6,9 \%\end{array}$ & $\begin{array}{l}5280249 \\
- \\
18,4 \%\end{array}$ & $\begin{array}{l}1680671 \\
- \\
5,9 \%\end{array}$ & $\begin{array}{l}28654440 \\
- \\
100 \%\end{array}$ \\
\hline 2004 & $\begin{array}{l}5635372 \\
- \\
49,7 \%\end{array}$ & $\begin{array}{l}4580675 \\
- \\
40,4 \%\end{array}$ & $\begin{array}{l}957081 \\
- \\
8,4 \%\end{array}$ & & $\begin{array}{l}174112 \\
- \\
1,5 \%\end{array}$ & $\begin{array}{l}11347241 \\
- \\
100 \%\end{array}$ \\
\hline
\end{tabular}

\subsection{Místní úroveň}

\section{Société d'économie mixte}

Pro brownfields, které nepředstavují závažný problém v území a $\mathrm{v}$ krátké době pro ně bude možné nalézt nové využití je regenerace přenechávána městům. Jeden z hlavních nástrojů využívaných při regeneracích městského prostředí jsou SEM, jedná se o formu partnerství mezi veřejným a soukromým sektorem. Francie patř́ mezi jedny z prvních evropských zemí, které tuto formu spolupráce začaly využívat.

SEM lze označit za institucionální typ public private partnership. Dává vzniknout jednomu subjektu, ovládanému a řízenému jak soukromým, tak veřejným sektorem, který bude dodávat služby veřejnosti. Jedná se tedy o tzv. joint venture. Veřejnému sektoru je umožněno kontrolovat projekt, dohlížet na jeho kvalitu a využít zkušenosti soukromého sektoru. Jsou tak rozloženy vysoká rizika a náklady. Veřejný sektor se může podílet na společnosti vkladem kapitálu nebo pozemku. Joint venture může být finančního charakteru nebo se může jednat o rozvojový typ. Rozvojový typ je zaměřen na tvorbu strategie a snaží se přilákat do zvoleného řešení co největší množství prostř̌edků a zkušeností $\mathrm{z}$ veřejného i soukromého sektoru (CzechInvest, 2007).

Société d'économie mixte (SEM) - smíšené společnosti, se mohou podílet na realizaci jednoho konkrétního projektu nebo mohou být založeny pro více projektů najednou. Tyto projekty mohou být zaměřeny také na regenerace brownfields. Jedná se o akciovou společnost, jejíž kapitál drží v rukou převážně místní samosprávy a to bud' př́ímo, nebo prostř̌ednictvím veřejné organizace. Částečně jsou držitelé akcií také soukromé subjekty. Veřejný sektor má tedy v SEM nadpoloviční zastoupení $(51$ \%$-85 \%$ ), čímž si zajistí možnost rozhodovat, kontrolovat a dohlížet na kvalitu projektů. Dalšími účastníky mohou být banky, nejčastěji to bývá Caisse de dépôts et consignations. Francouzská státní banka velice často spolupracuje s regiony, departmenty a městy a podílí se na financování projektů, které jsou zaměřeny na výstavbu infrastruktury, sociálního bydlení a projekti̊ přispívajících 
k udržitelnému rozvoji. Dalšími partnery v SEM bývají vlastníci pozemků, stát, region a departmenty. SEM realizují rozvojové projekty, zajištují výstavbu a provoz veřejných zařízení průmyslového nebo komerčního charakteru př́padně jakékoliv jiné aktivity, které mají prospěch pro veřejnost (TechnoScience.net, 2013). Město uděluje SEM půjčku, podílí se na nákladech týkajících se veřejného vybavení, které prresahují rozpočet a zároveň jsou využívány finance $\mathrm{z}$ městského rozpočtu $\mathrm{v}$ případě problémů při realizaci projektu (CzechInvest, 2007).

\section{Př́padové studie regenerací}

EPF pozemky předpřipravuje pro budoucí využití, navrací je do stavu srovnatelného s greenfields. Takovým projektem je např́íklad regenerace území bývalé továrny sloužící chemickému průmyslu, Knox-Vroone. Projekt realizovaný prostřednictvím SEM je EuraTechnologie.

\subsection{Knox-Vroone1}

Areál se nachází v departmentu Nord, v arrondissementu Valenciennes, v obci Escaudain. Areál o velikosti 2,5 ha dříve sloužil výrobě mýdel, čistících prostředků a minerálních olejů. Od roku 1909 zde sídlila společnost Lampereur vyrábějící mýdla. Později zde měla sídlo společnost Vroone vyráb̌̌jící produkty ze dřeva, která se časem spojila se společností Knox. Společnost Knox-Vroone zde již fakticky nikdy nepůsobila a budova zůstala opuštěna.

Složité majetkoprávní vztahy byly vyřešeny převedením areálu na EPF, která se stala rovněž realizátorem projektu zaměřeném na regeneraci území. Rekonverze se uskutečňovala v letech 20042006. Lokalita se nacházela v blízkosti městské zástavby a samotnou realizaci předcházely rozsáhlé studie o rozsahu znečištění. $Z$ důvodu nenalezení vhodného využití areálu došlo k jeho demolici. Území bylo zbaveno ekologických zátěží, navráceno mezi greenfields a připraveno na opětovné využití. Uskutečněné operace umožnily odstranit rizika, které lokalita představovala pro zdejší obyvatele a životní prostředí. Zdroje financí EPF uvádí následující tabulka.

Tabulka č. 2: Zdroje financování projektu (€)

\begin{tabular}{|l|l|l|l|l|}
\hline Stát & Region & Město & EU - ERDF & Celkem \\
\hline 59595 & 150961 & 112232 & 402220 & 725008 \\
- & - & - & - & - \\
$8 \%$ & $20 \%$ & $16 \%$ & $56 \%$ & $100 \%$ \\
\hline
\end{tabular}

Zdroj: Ministère de l'Écologie, de l'Énergie et du Développement durable

\subsection{EuraTechnologie}

Projekt byl realizován v metropoli Lille ${ }^{2}$, kde v minulosti dominoval těžební a textilní průmysl. Během 90. let začal být průmysl nahrazován službami, vědou a výzkumem. Mezinárodní význam metropole postupně narůstal, zejména díky vhodné regionální rozvojové strategii, za jakou lze považovat právě Schéma directeur de développement d'urbanisme de Lille Metropole (2002-2015). V dokumentu byly vymezené póly rozvoje, v rámci kterých se realizovalo 5 rozvojových projektů uvedených v následující tabulce. Řadíme mezi ně i projekt EuraTechnologie (Veselý, 2005).

\footnotetext{
${ }^{2}$ Metropole Lille - tímto názvem je označována aglomerace kolem města Lille, kterou tvoří 126 obcí. Hlavními centry této aglomerace jsou města Lille, Roubaix, Tourcoing a Villeneuve d'Ascq.
} 
Tabulka č. 3: Rozvojové projekty Lille Métropole

\begin{tabular}{|l|l|l|}
\hline Název & Lokalita & Zaměření \\
\hline Euralille & Lille & $\begin{array}{l}\text { Nádraží TGV, služby } \\
\text { (kanceláře), obchod, bydlení }\end{array}$ \\
\hline L‘Union & $\begin{array}{l}\text { Mezi městy Roubaix, } \\
\text { Tourcoing a Wattrelos }\end{array}$ & $\begin{array}{l}\text { Věda a výzkum, moderní } \\
\text { aktivity spojené s textilním } \\
\text { prummyslem }\end{array}$ \\
\hline Eurasanté & Mezi městy Lille a Loos & $\begin{array}{l}\text { Univerzita podnikatelský park } \\
\text { voborech spojených s lidským } \\
\text { zdravím }\end{array}$ \\
\hline $\begin{array}{l}\text { Parc scientifique de la Haute } \\
\text { Borne }\end{array}$ & Villeneuve d‘Ascq & Služby (kanceláře), bydlení \\
\hline $\begin{array}{l}\text { Euratechnologie: Rives de la } \\
\text { Haute Deûle }\end{array}$ & Mezi městy Lille a Lomme & Technologický park, bydlení \\
\hline
\end{tabular}

Zdroj: Lille Métropole, vlastni zpracování

Součástí dokumentu byl také generel dopravy, jehož cílem bylo napojení metropole Lille na evropské metropole a propojení jednotlivých měst v regionu prostřednictvím veřejné dopravy. Část dokumentu se věnovala ochraně životního prostředí a dostatečné nabídce zelených a odpočinkových ploch. Cílem těchto 5 rozvojových projektı je zajistit ekonomický rozvoj metropole a upevnit její mezinárodní význam. Důraz je kladen na maximální využití brownfields a na zakomponování nového bydlení, včetně sociálního do vnitřní struktury sídel. Strůjcem a iniciátorem této proměny byl dlouholetý starosta metropole pan Pierre Mauroy (Veselý, 2005).

\section{Původní využití}

Technologický park je umístěn v bývalé textilní továrně Blan Lafont, která sloužila na zpracování bavlny a lnu. Po více než stoleté existenci došlo v roce 1983 k jejímu uzavření (Lille Métropole, 2009).

\section{Charakteristika projektu a současné využití}

Komunikační a informační technologie řadíme mezi nezbytné služby pro rozvoj podnikání. Usnadňují nejen správu podniku, ale zároveň komunikaci a předávání informací. O ICT technologie se dnes opírá hospodářský růst. V regionu Nord-Pas-de-Calais se soustředí přibližně 4000 podniků zaměřených na ICT technologie, z čehož více než polovina je situována na periférii Lille. Stěžejní význam technologií pro ekonomiku regionu je tedy zřejmý. Metropole Lille v roce 1999 představila projekt na vybudování centra informačních a komunikačních technologií. Realizací a rozvojem projektu byla v roce 2003 pověřena SEM Soreli. Práce na regeneraci trvaly v letech 2006-2009 (Lille Métropole, 2009).

Technologický park se stal součástí projektu Rives de la Haute Deủle, který se realizuje ve čtvrti Bois Blanc rozkládající se na 100 ha. Operace EuraTechnologie je první fází dvacetiletého projektu. Další práce se týkají výstavby kanceláŕí, bydlení a veřejné vybavenosti. Projekt ztělesňuje prvky vysoké kvality životního prostředí, udržitelného rozvoje, architektonických inovací a moderních technologií. Celková rozloha samotného areálu jediného svého druhu na sever od Paříže činí $22000 \mathrm{~m}^{2}$. Dnes zde sídlí 85 podniků zaměstnávajících 1400 osob. Předpokládá se ovšem nárůst na 6000-8000 osob. Technologický park nabízí High-tech služby, modulární kanceláře, video-konferenční místnosti, inkubátor pro podniky podnikající v oblasti ICT technologií, auditorium pro 300 osob, digitální studio, recepce, konferenční a seminární místnosti, restaurace, kavárna, atrium atd. Cílem projektu bylo podpořit nejen ekonomický rozvoj metropole a regionu, ale zároveň rozvoj komunikačních a informačních technologií $\mathrm{v}$ metropoli, která je součástí jednoho $\mathrm{z}$ pěti nejatraktivnějších regionů pro rozvoj daných technologií ve Francii. Cílem bylo také nabídnout High-Tech služby a udělat z metropole Lille centrum evropského významu v oblasti ICT technologií (Lille Métropole, 2009). Následující tabulka shrnuje zdroje financí, jejich výši a procentuální podíl na celkových nákladech. 
Tabulka č. 4: Zdroje financování projektu $(\epsilon)$

\begin{tabular}{|l|c|c|}
\hline Zdroje financí & Celková výše & $\%$ \\
\hline Region & 9000000 & 17,5 \\
\hline Stát & 8975000 & 17,5 \\
\hline Evropa & 3000000 & 5,8 \\
\hline Conseil Général & 2000000 & 3,9 \\
\hline Město Lille & 550431 & 1,1 \\
\hline Celková výše dotací & 23525431 & 45,8 \\
\hline Lille métropole & 27788200 & 54,2 \\
\hline Celková výše financí & 51313631 & 100 \\
\hline
\end{tabular}

Zdroj: Lille Métropole, vlastní zpracování

Projekt EuraTechnologie ukazuje, že regenerace přispívá k rozvoji informačních a komunikačních technologií. Projekt vytvořil nová pracovní místa a z metropole se postupně stává centrum ICT technologií mezinárodního významu. Zároveň díky zachování historické budovy a jejího industriálního charakteru se jedná o spojnici mezi minulostí a současností. Z projektů je také patrný význam a síla veřejného sektoru, který dokáže realizovat rozsáhlé projekty a konkurovat soukromému sektoru.

\section{Závěr}

Ačkoliv Francie a Česká republika jsou naprosto odlišné země, které nelze srovnávat a zavádění většiny francouzských nástrojů je velice obtížné a těžko myslitelné, existují nástroje, jejichž zavedení v ČR by bylo reálné a zásadní pro procesy regenerací. Jedná se o organizaci EPF a nástroj SEM.

EPF odstraňuje bariéry, které znevýhodňují výstavbu na brownfields, oproti výstavbě na greenfields. Organizace navrací již jednou využívané pozemky zpátky na trh, zabraňuje tak zbytečnému zabírání nových greenfields, čímž nedochází k neustálému plýtvání neomezených zdrojü, které představují „zelené plochy“. Její činnost je v souladu s principy udržitelnosti a pozitivně přispívá k rozvoji regionu.

Nástroj SEM využívaný na místní úrovni a forma spolupráce daného typu by byla rovněž př́nosná. Tento nástroj by mohl zejména $\mathrm{v}$ období hospodářské krize přilákat investory a oživit ekonomiku zejména $\mathrm{v}$ hospodářsky slabých oblastech. Napomáhá také $\mathrm{v}$ řešení finančních problémů při procesech regenerací. Tento nástroj umožňuje rozložit vysoké náklady, které by nebyl schopen veřejný nebo soukromý sektor sám unést. Právě vysoké finanční náklady jsou jedním z hlavních důvodů, proč investoři nesměřují své investice do brownfields. Zároveň prostřednictvím tohoto nástroje dojde k rozložení vysokých rizik spojených s lokalitami brownfields. Další výhody plynou z možnosti municipality kontrolovat projekt a dohlížet na jeho kvalitu. Při realizaci projektu formou SEM mohou být využity zkušenosti odborníků ze soukromého sektoru, kterému veřejný sektor zejména v podmínkách ČR nedokáže stále konkurovat.

\section{Literatura}

[1] CZECHINVEST. Národni strategie regenerace brownfieldů. 2008, 12 s. Dostupné z: $<$ http://www.czechinvest.org/data/files/strategie-regenerace-vlada-1079.pdf $>$.

[2] CZECHINVEST. Národni strategie regenerace brownfieldu. Praha, 2007. $117 \mathrm{~s}$.

[3] DOLEŽELOVÁ, L. Regenerace brownfields - Zahranični zkušenosti (Studie př̀ikladi̊ Anglie, Francie, Belgie - Flandry a Nizozemi), IURS, prosinec 2004. 12-13 s. 
[4] EPF NORD-PAS-DE-CALAIS. Histoire d'une contribution: 14 ans de requalification de friches industrielles dans la région Nord-Pas-de-Calais. 2006. $3 \mathrm{~s}$.

[5] ÉTABLISSEMENT PUBLIC FONCIER. Site de lÉtablissement public foncier [online]. 2013 [cit. 2013-05-01]. Dostupné z: <http://www.epf-npdc.fr/>.

[6] LILLE MÉTROPOLE. Euratechnologies. 2009. Dostupné z: $<$ http://www.lillemetropole.fr/gallery_files/site/123919/156997.pdf $>$.

[7] MINISTERE DE L'ÉCOLOGIE, DE L'ÉNERGIE ET DU DÉVELOPPEMENT DURABLE. Friches industrielles et pollutions historiques [online]. 2010 [cit. 6.12.2012]. Dostupné $\quad \mathrm{z}: \quad<\mathrm{http} / / \mathrm{www}$.developpement-durable.gouv.fr/amenagement-et-sitespollues/pdf/Friches-industrielles-et-pollutions-historiques-LMCU-19-04.pdf>.

[8] MINISTERE DE L'ÉCOLOGIE, DE L'ÉNERGIE ET DU DÉVELOPPEMENT DURABLE. Site KNOX-VROONE [online]. 2007 [cit. 22.3.2013]. Dostupné z: $<\mathrm{http}: / / \mathrm{www} . d e v e l o p p e m e n t-d u r a b l e . g o u v . f r /$ amenagement-et-sitespollues/pdf/DDENordKnoxVroone.pdf $>$.

[9] Société d'économie mixte. Techno-Science.net [online]. 2013 [cit. 2013-03-22]. Dostupné z: $<$ http://www.techno-science.net/?onglet=glossaire\&definition=798>.

[10] VESELÝ, Robert. Francouzské př́stupy k plánování měst. Urbanismus a územní rozvoj. 2005, roč. 8 , č. $6 . \quad 29$ s. Dostupné z: <http://www.uur.cz/images/publikace/uur/2005/200506/08_francouzske.pdf>. 